\title{
Electrophysical Monitoring of the Processes of Electroosmotic Treatment of Soil from Oil Pollution on Laboratory Installations
}

\author{
Shabanov Evgeniy A. ${ }^{\mathrm{a}}$, Prostov Sergey M. ${ }^{\mathrm{b}}$ \\ T. F. Gorbachev Kuzbass State Technical University \\ Kemerovo, 650000, Russian Federation \\ aevgenshab@mail.ru, bssm.kem@mail.ru
}

\begin{abstract}
This article describes methods and results of laboratory simulation of processes in the clay soils contaminated by oily substances in the samples, on the one-dimensional and three-dimensional physical models. It describes the laboratory setup, the procedure for conducting experiments and processing their results. The possibility of point and integrated prediction of the degree of contamination of the soil on the measurements of its electrical resistance was confirmed. The behavior of changes of porosity, moisture content, granulometric composition of soils contaminated with oil products when there are electrically treated due to thermal and osmotic effects was identified by comparing the data of direct measurements and of electrical control by the system of microprobes. The comparison of results of electrical treatment of the clean soil contaminated with liquid and viscous oil p;roducts, as well as by over-exposure to the active substance - solvent was given.
\end{abstract}

Keywords-clay soils, petroleum products, pollution, electroosmos, electrical resistivity, porosity, moisture content, granulometric composition.

\section{INTRODUCTION}

The most common contaminants are oil and petroleum products. Accidents at the oil-producing plants during transportation of oil lead to catastrophic consequences. In the absence of emergency situations, contamination of soils with oil products occur in massive volumes. Thus, at mining and coal processing enterprises of Kuzbass similar events occur in the stationary and mobile fuel and oil filler areas, warehouses of fuel and lubricants, and a significant amount of contaminants occur in the soil of the foundations of existing buildings and facilities, which complicates or eliminates their mechanical removal for decontamination [1].

Methodological approaches to address the problems of cleaning soil from pollution are considered in the fundamental monograph [2]. Recent studies conducted by various organizations are aimed at the development of physical and chemical $[3,4]$, biological $[5,6,7]$ decontamination techniques, or combinations thereof $[8,9]$, while emphasizing that when the point (local) sources of pollutant emissions (pollutants) are addressed, this increases the importance of monitoring methods (location of zones of pollution, monitoring changes in the concentration of toxicants) $[10,11]$.

Promising treatment for decontaminating of soils with low permeability is application of the electrochemical method, which combines the transmission of high density current through the soil mass, electroosmotic saturation of soil with active liquid diluting viscous components or deactivating the contaminant, and removal of the solutions containing dissolved contaminants. Experimental and theoretical basics of electro osmotic processes set forth in [12] found practical application in reclamation (dewatering and drainage) and construction (grouting by chemical solutions) [13, 14]. Due to the complexity and lack of knowledge of the complex physical and chemical processes during electrical treatment as well as the power consumption of this method, this method has not yet received the mass distribution.

The idea of using an electrochemical method for cleaning soil from oil and other pollutants and toxicants is developed at MSU under the guidance of prof. V.A. Korolev. The results of fundamental research of electrosurface phenomena in clay rocks proved the practical significance of the research areas [15-18].

Another unresolved issue is the control of soil treatment processes at various stages of this line of research developed in the laboratory of geocontrol KuzSTU.

The basic premise of physical control method is that all used in road and rail transport petroleum products (oil, diesel, gasoline) exhibit pronounced dielectric properties. Effective resistivity (resistivity) of the liquid ranges $\rho=10^{10}-10^{12}$ $\mathrm{Om} \cdot \mathrm{m}$, while for solutions of natural mineral, the range is $\rho=$ $0.1-100 \mathrm{Om} \cdot \mathrm{m}$ electrical resistivity moisture saturation of the rock, which is a three-phase medium determined using the classical empirical relationship [19-20]

$$
\rho_{k}=\frac{\alpha k_{n}}{m^{\beta} W^{\gamma}} \rho_{b},
$$

where $m$ - porosity (pore cavernosity); $W$ - moisture saturation ratio of the pore spaces and cracks; $\rho_{b}$ - Electrical resistivity filling the pore space of solution, Om.m; $k_{n}, \alpha, \beta, \gamma-$ empirical parameters, which depend on structural and textural characteristics of the soil; $k_{n}$ - parameter taking into account the surface conductivity of the clay layer on the micro pore surface; $\alpha$-parameter depending on the type of geological deposits; $\beta$ - parameter determined mainly by tortuosity; $\gamma-$ parameter depending on the wettability of the pore surface by the solution. 
The value of parameters $k_{n}$ and $\alpha$ for the coal-bearing and coal enclosing deposits of one type can be taken equal to 1 [21]. The parameter $\beta$ depends on the structure of the pore space and for compacted loose soils it varies in the range $\beta=$ 1.3-2.2; the parameter $\gamma$ is determined by the degree of wettability of the solid phase surface and varies in the range $\gamma$ $=1.8-3.5$.

Ranges of parameters $\beta$ and $\gamma$, are obtained by inverse calculations using experimental data bank $\rho_{k} / \rho_{b}$ as well as averaged values of the physical and technical parameters $\bar{m}$ and $\bar{W}$ for the main types of clay soils of Kuzbass [22].

To evaluate the pollutant content in the pore fluid, it is advisable to use the theoretical dependence of the logarithmic weighted average for the two-component environment that allows calculation of the desired value with high reliability [23]:

$$
\lg \rho_{b}=V_{n} \lg \rho_{n}+V_{e} \lg \rho_{e},
$$

where $\rho_{b}, \rho_{n}, \rho_{e}$ - electrical resistivity of weighted average oil and electrolyte respectively, Om.m; $V_{n}, V_{e}$ - the volume in the solution of oil and electrolyte respectively.

Theoretical dependences (1) and (2) in principle allow the assessment of the degree of soil pollution with oil products based on the results of individual measurements, longitudinal and areal electrical soundings [24, 25].

This work is devoted to experimental verification of the presented idea using soil samples and laboratory facilities.

\section{MATERIALS AND METHODS}

The complex of laboratory research includes the following experiments:

- Verification of the calculated dependencies on soil samples with a given pollution;

- Simulation of electrochemical processing on onedimensional model;

- Simulation of electrochemical processing of threedimensional model.

To compare the theoretical and experimental results, coefficient $k$ of soil contamination is introduced equal to the ratio of the volume of oil products contained in the pores to the total volume of the pore fluid. By transformation of the equations (1) and (2) it is possible to obtain the following expression:

$$
k=\frac{V_{H}}{V_{H}+V_{\ni}}=\frac{\ln \left(\frac{\rho_{k} m^{\beta} W^{\gamma}}{\alpha \kappa_{n} \rho_{e}}\right)}{\ln \left(\frac{\rho_{n}}{\rho_{e}}\right)}
$$

Samples of contaminated soil were prepared by mixing the pure soil by mixer with the fixed amount of engine oil. For artificially contaminated samples of soil we measured in the experiment porosity, moisture, electrical resistivity of ground $\rho_{k}$, electrolyte $\rho_{e}$ and pore fluid $\rho_{n}$, as well as soil pollution factor $k$ with the help of specially designed software package that provides the cyclic selection of the optimal values of the constants $\beta$ and $\gamma$.

One-dimensional physical model of electrochemical treatment zone had a cylindrical shape with the distance between the electrodes in a horizontal direction close to the real, $l=0.3 \mathrm{~m}$ (Figure 1).

As the test environment we used compacted clay loam mixed by a mixer with a petroleum product. The container for the soil was a tube of non-conductive material (polyethylene) with the pipe outside diameter $160 \mathrm{~mm}$, and inside diameter $140 \mathrm{~mm}$. The plates made of galvanized steel $0.7 \mathrm{~mm}$ thick were attached to the ends of the tube and cut to the crosssection of the tube. The lower part of the tube near electrodes 5, 6 there are drainage openings 11 provided. In order to increase the current density, $800 \mathrm{~g}$ of water and $8 \mathrm{~g}$ of sodium salt $\mathrm{NaCl}(1 \%)$ were added to the ground prior to filling it in the tube.

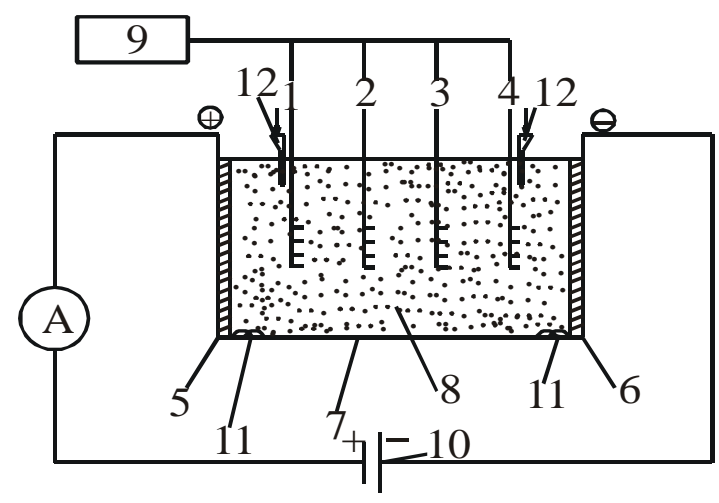

Fig. 1 Experimental one-dimensional modular installation: 1-4 - four-electrode sensor-probes \# 1-4; 5 - positive electrode (anode); 6 - a negative electrode (cathode); 7 - PE pipe $\varnothing 160 \mathrm{~mm} ; 8$ - treated contaminated soil; 9 - CP-2 logging tool; 10 - constant voltage source $U=16 \mathrm{~V} ; 11$ drainage holes; $A, M, N, B$ - copper microelectrodes; 12 holes for supplying solvent

The experimental procedure consisted of measuring the resistivity of contaminated soil using probe-sensors made of four-core copper cable. Sensor microprobes with the distance between contacts $A M=M N=N B=10 \mathrm{~mm}$ are immersed into the soil through the holes in the tube to the depth of $70 \mathrm{~mm}$. The measuring device is a logging tool CP-2, which implements the measurement of the electrical resistivity at constant current in pulsed mode with automatic compensation of polarization developed in KuzSTU. The rest of the electrical characteristics of the ground and installations were measured by electronic multimeter MY64. The electric field in the model was created with stabilized power supply with a voltage of $U=12-16 \mathrm{~V}$. 
Physical and mechanical soil characteristics were determined using the following devices and equipment of the field laboratory PLL-2: a set of weighing bottles to determine humidity, electronic scales, oven, set of sieves.

The volume (three-dimensional physical) model presented a portion of the area of electrochemical purification with the actual transverse dimensions of the electrodes and distance between them in the horizontal section (Figure 2).

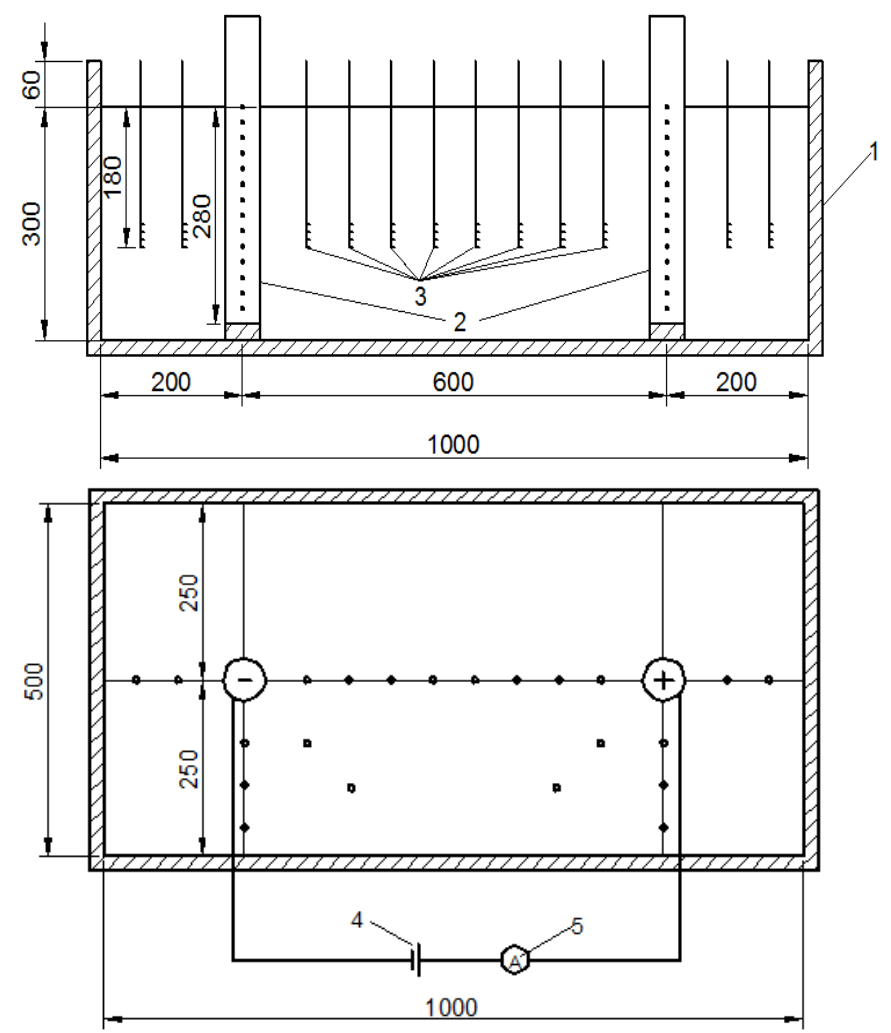

Fig. 2 The experimental setup of three-dimensional model: 1 - container (bath); 2 - electrodes, injectors; 3 microprobe sensors; 4 - supply unit (two series-connected sources of DC power supply B5-50); 5 - ammeter

As the test environment, the compacted clay loam mixed by a mixer with a petroleum product was used. Concentration of the oil pollutant corresponded to the actual possible pollution caused by gradual periodic pollution or oil spill resulting from the accident. Thus, all the physical parameters of the model didn't differ from those of the nature.

The container with dimensions $1000 \times 500 \times 360 \mathrm{~mm}$ was made of non-conductive for electrical current material (laminated waterproof plywood) waterproofed with plastic wrap and filled with loam. In the ground to the depth of 300 $\mathrm{mm}$ we immersed electrodes-injectors - perforated steel electric-welded pipes with an inner diameter of $51 \mathrm{~mm}$ tapped at the bottom with a wooden plug.

The experimental procedure consisted of measuring the true resistivity of the contaminated soil using microprobe sensors described above immersed in the soil to the depth of $180 \mathrm{~mm}$. The total number of sensorswas - 22. The electric field in the model was created by the stabilized power supply unit B5-50 with a voltage of $U=50-300 \mathrm{~V}$, with current up to $0.6 \mathrm{~A}$.

\section{RESULTS AND DISCUSSION}

In the experiment with artificially contaminated samples, starting from sample number 7 , there was a partial violation of the structural relations of the sample. With the increased concentration of oil at $k>30 \%$, there was a change of the phase state of the sample: its transition from a solid bound to a plastic non-bound suspension, which contributed to a sharp increase in electrical resistivity of the sample. Scope of the proposed control method is limited $k<20 \%$, the estimation error does not exceed $23 \%$ (Table 1)

TABLE.1 The physico-mechanical characteristics of the ground in test samples (soil mass $m_{g}=200 \mathrm{~g}$, water mass $m_{b}=$ $20 \mathrm{~g}$, wetness $W=22 \%$ )

\begin{tabular}{|c|c|c|c|c|c|c|c|c|c|c|}
\hline \multirow{2}{*}{ Characteristic } & \multicolumn{7}{|c|}{ \# sample } \\
\cline { 2 - 12 } & 1 & 2 & 3 & 4 & 5 & 6 & 7 & 8 & 9 & 10 \\
\hline Mass of oil, g & 0 & 2 & 4 & 10 & 15 & 20 & 30 & 40 & 50 & 60 \\
\hline $\begin{array}{c}\text { Electrical resistivity of } \\
\text { soil, } \rho_{k}, \text { Om·m }\end{array}$ & 13.75 & 17.5 & 21.25 & 23.75 & 22.5 & 25 & 26.25 & 42.5 & 950 & 1150 \\
\hline Porosity, $m, \%$ & 38.8 & 40.7 & 42.5 & 48.1 & 52.7 & 57.4 & 66.7 & 76 & 85.3 & 94.6 \\
\hline$k, \%$ & 0 & 1 & 1.8 & 4.35 & 6.4 & 8.3 & 12 & 15.4 & 18.5 & 21.4 \\
\hline
\end{tabular}

For the geophysical express forecast one can choose regression dependence, quite accurately describing the behavior of the contamination factor $k$ with increasing concentration of oil in the ground and a corresponding increase in the relative electrical resistivity $\rho_{k}$. Table 2 shows the results of statistical processing - the regression equation and the corresponding estimates of: the ratio of the correlation (correlation coefficient) $R$; Fisher's exact test, $F$; critical Fisher criterion, $F_{k p}$. The greatest precision is provided by polynomial dependence $(R=0.981)$.

TABLE 2 The dependence of $\mathrm{k}$ pollution factor on the relative change in the soil electrical resistivity in the soil sample

\begin{tabular}{|c|c|c|c|}
\hline The equation & $R$ & $F_{k p}$ & $F$ \\
\hline$k=9.49 \frac{\rho_{k}}{\rho_{k 0}}-10.61$ & 0.900 & 7.709 & 17.356 \\
\hline$k=12.52 \ln \left(\frac{\rho_{k}}{\rho_{k 0}}\right)-1.19$ & 0.867 & 7.709 & 12.287 \\
\hline$k=18.57\left(\frac{\rho_{k}}{\rho_{k 0}}\right)^{2}-42.7257 \frac{\rho_{k}}{\rho_{k 0}}+24.44$ & 0.981 & 9.552 & 81.746 \\
\hline$k=0.19\left(\frac{\rho_{k}}{\rho_{k 0}}\right)^{6.1022}$ & 0.977 & 7.709 & 93.087 \\
\hline
\end{tabular}


In the graphical form the experimental results are presented in Figure 3

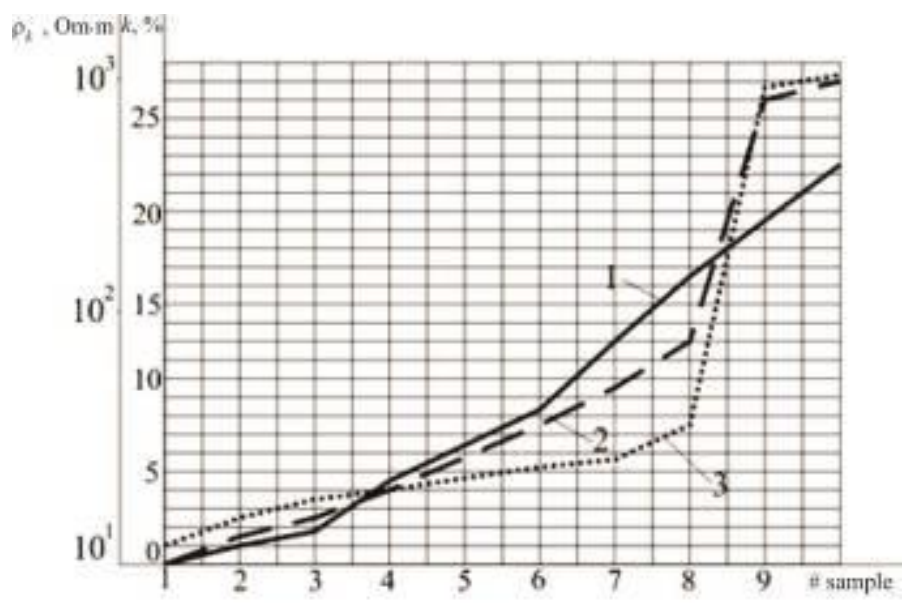

Fig. 3. The results of the experimental determination and software calculation of the pollution factor in soil samples:

$1-k$ coefficient obtained experimentally; 2 - calculated coefficient; 3 - resistance $\rho_{k}$ in soil samples

$a$

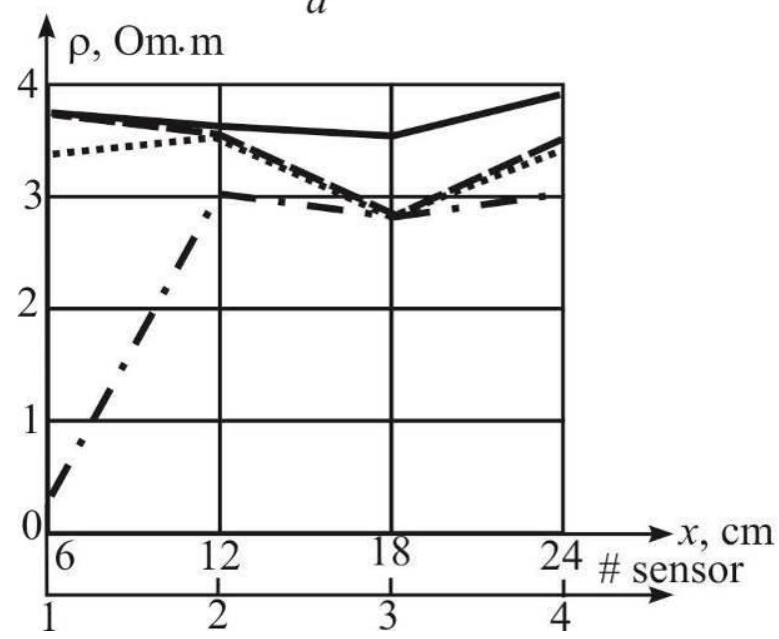

The main objectives of experimental research on the onedimensional model (see Figure 1) were as follows: establish the effect of heating the soil mass by electric current on the decomposition of organic substances; study the physical parameters of the soil mass to be cleansed; study electrocoagulation processes facilitating the transition of oil in the solid state.

Figure 4 shows the results of measurements of the treated soil resistivity depending on the location of the $x$-coordinates of sensor probes in the installation within a time range.

It follows from the graph that the physical processes in the electric treatment for 6 days of pure and contaminated with oil soils are fundamentally different: the pure soil sample shows electroosmotic movement of moisture into the anode area; in the contaminated sample it was recorded that the fluid moved in both directions while oil products were moving by pores towards the cathode. Through the drain holes discharge of accumulated fluid was observed: at the anode with minor traces of oil, at the cathode - their notable content.

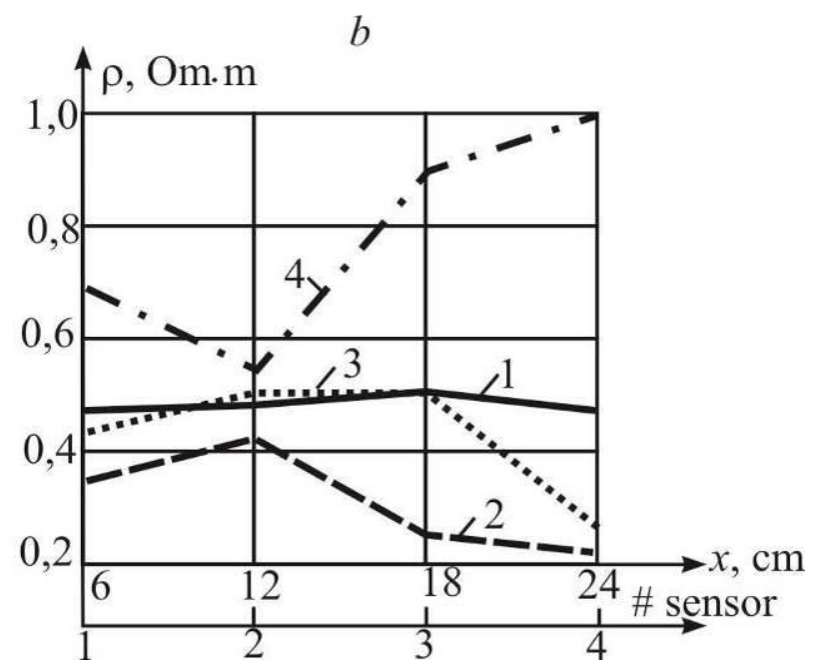

Fig. 4. Changing the electrical resistivity of clean soil $(a)$ and contaminated with oil SHELL HELIX $(b)$ with the addition of a solution $\mathrm{NaCl}$ in electrochemical processing: 1 - start of treatment; 2 - after 1 day; 3 - 2 days; 4 - 6 days

Figure 5 shows the results of control of the relative change in electrical resistivity $\rho / \rho_{0}$ along the longitudinal axis of the tube during the processes of soil electric treatment and after its termination. Changes in the basic physical parameters of the soil near sensors \#1 and \# 4 (in the areas of main electroosmosis) are shown in Table 3 , the changes in the size distribution are shown in Table 4. The experiments described above allow to evaluate electrothermal treatment effects on the ground massif without dissolving thick petroleum fractions.

Experiments were performed with thinning of oil polluter. The setup was loaded with clay loam mixed with water $(800$ $\mathrm{g})$, oil (170 g) and sodium chloride (12 g). In the experiment, the contaminated soil was treated by electric current and then the soil was flushed with oil solvent $n$-Hexane.

Washing liquid was fed into the hole in the tube near sensor 1 at time $t_{1}=64$ hours from the start of the experiment in the volume of $100 \mathrm{ml}(70 \mathrm{~g})$. Also the washing liquid was fed near sensor number 4 at the time of $t_{2}=136$ hours from the start of the experiment to the volume of $100 \mathrm{ml}(70 \mathrm{~g})$. During the experiment, liquid accumulated under the negative, by its properties it was close to the properties of the water, the accumulation occurred uniformly throughout the experiment, the total volume of the liquid volume was $150 \mathrm{ml}$.

When feeding hexane to sensor \# 1, the liquid was spreading in the soil mass without dripping under the electrodes. When applied to sensor \#4, hexane dripped under the negative electrode, the total liquid volume was $20 \mathrm{ml}$ (14 g). The graphs of the relative change in resistivity (Figure 6) show that in the zone of oil products liquefaction and dissolution an additional reduction of electrical resistivity value was observed. 

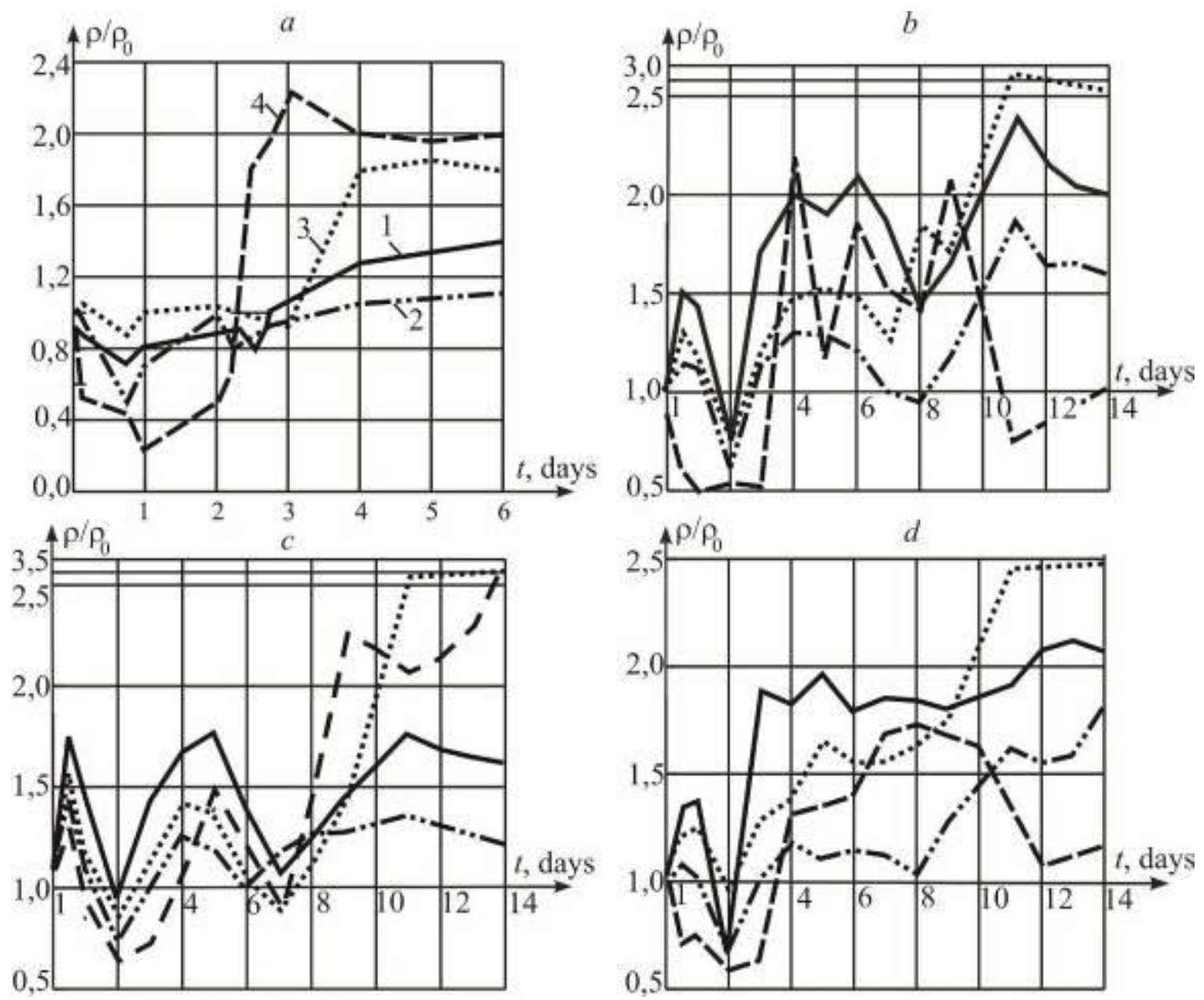

Fig. 5. Graphs of changes in the relative electrical resistivity of the soil mass during electrochemical purification from oil Shell Helix Ultra pollution by (a); gasoline (b); spent oil Shell Helix Ultra (c); diesel (d) (the amount of pollutant V= $100 \mathrm{~g}$ ): 1 - a four-electrode sensor probe \# $1 ; 2-\# 2 ; 3-\# 3 ; 4-\# 4$

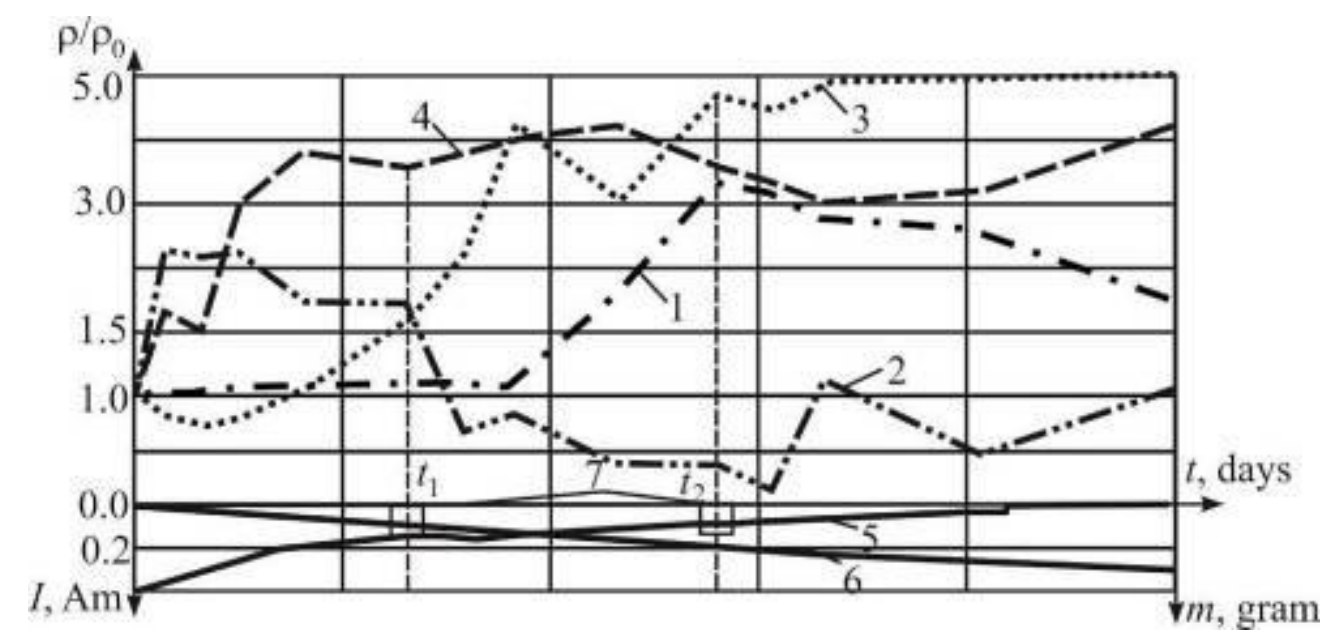

Fig. 6. Graphs of changes in the relative electrical resistivity of the soil mass, current $I$ and mass $m$ of flushing liquid feed during electrochemical decontamination by Shell Helix Ultra oil, and washing by hexane-n solvent: 1 - a four-electrode sensor probe \# $1 ; 2-\# 2 ; 3-\# 3 ; 4-\# 4 ; 5$ - current $I$;

6 - mass of water accumulated under the negative electrode; 7 - the amount of the supplied washing liquid; $t_{1}, t_{2}-$ the interval of solvent introduction 
TABLE 3. Change of the physical parameters as a result of the electric treatment

\begin{tabular}{|c|c|c|c|}
\hline \multirow[b]{2}{*}{$\begin{array}{l}\text { Figure, } \\
\text { \# sensor }\end{array}$} & \multicolumn{3}{|c|}{ Characteristics (before / after treatment) } \\
\hline & $\begin{array}{c}\text { wetness, } \\
\%\end{array}$ & $\begin{array}{c}\text { density } \\
\text { in wet } \\
\text { condition, } \mathrm{g} / \mathrm{sm}^{3}\end{array}$ & $\begin{array}{c}\text { density } \\
\text { in dry } \\
\text { condition, } \mathrm{g} / \mathrm{sm}^{3}\end{array}$ \\
\hline Fig. 5, $a, \# 1$ & $54 / 15$ & $2.33 / 1.72$ & $1.51 / 1.49$ \\
\hline Fig. 5, $b, \# 1$ & $17.3 / 12.2$ & $1.80 / 1.66$ & $1.53 / 1.48$ \\
\hline Fig. 5, $c, \# 1$ & $15.9 / 9.3$ & $1.81 / 1.61$ & $1.56 / 1.47$ \\
\hline Fig. 5, $d, \# 1$ & $19 / 16$ & $1.81 / 1.74$ & $1.52 / 1.50$ \\
\hline Fig. 5, $a, \# 4$ & $54 / 52$ & $2.33 / 2.3$ & $1.51 / 1.51$ \\
\hline Fig. 5, $b, \# 4$ & $17.3 / 16.0$ & $1.80 / 1.74$ & $1.53 / 1.5$ \\
\hline Fig. 5, $c, \# 4$ & $15.9 / 7.5$ & $1.81 / 1.62$ & $1.56 / 1.51$ \\
\hline Fig. 6, \# 1 & $33 / 18$ & $2.04 / 1.92$ & $1.53 / 1.63$ \\
\hline Fig. 6, \# 4 & $33 / 14.3$ & $2.04 / 1.64$ & $1.53 / 1.43$ \\
\hline
\end{tabular}

TABLE 4. Change in the soil particle size distribution as a result of electrical treatment

\begin{tabular}{|c|c|c|c|c|c|}
\hline \multirow{2}{*}{$\begin{array}{c}\text { Fig., } \\
\# \text { sensor }\end{array}$} & \multicolumn{5}{|c|}{ The content of fraction (mm), \% (before / after treatment) } \\
\cline { 2 - 6 } & 2 & 0.5 & 0.25 & 0.1 & $<0.1$ \\
\hline Fig. 5, $a, \# 1$ & $0.9 / 3.6$ & $22.3 / 30.4$ & $12.2 / 14.6$ & $14 / 30.6$ & $50.6 / 20.75$ \\
\hline Fig. 5, $b, \# 1$ & $1.2 / 4.0$ & $19.3 / 32.3$ & $13.5 / 16.8$ & $16.6 / 25.4$ & $49.4 / 21.5$ \\
\hline Fig. 5, $c, \# 1$ & $2.0 / 2.1$ & $17.6 / 21.2$ & $15.5 / 22.3$ & $18.8 / 28.9$ & $46.1 / 25.5$ \\
\hline Fig. 5, $d$, \# 1 & $1.4 / 2.0$ & $19.8 / 31.1$ & $13.9 / 15.7$ & $16.1 / 28.8$ & $48.8 / 22.4$ \\
\hline Fig. 5, $b, \# 4$ & $1.2 / 1.5$ & $19.3 / 20.1$ & $13.5 / 14.0$ & $16.6 / 17.0$ & $49.4 / 47.6$ \\
\hline Fig. 5, $c, \# 4$ & $2.0 / 4.0$ & $17.6 / 20.1$ & $15.5 / 20.8$ & $18.8 / 23.6$ & $46.1 / 31.5$ \\
\hline Fig. 6, \# 1 & $7.7 / 10.6$ & $33.4 / 40.3$ & $15.1 / 15.1$ & $18.6 / 15.3$ & $25.2 / 18.7$ \\
\hline Fig. 6, \# 4 & $7.7 / 20.7$ & $33.4 / 39.1$ & $15.1 / 13.1$ & $18.6 / 24.1$ & $25.2 / 3$ \\
\hline
\end{tabular}

The analysis of the results led to the following conclusions:

- in heating during current flow and its impact on oil products in the pores of the soil, the oil products transit in a solid bound state, which increases the electrical resistivity of the soil throughout the treatment zone at $\mathrm{t}>3$ days;

- as a result of electrolytic impact of DC current on the polluted soil solid particles are formed and stick together resulting in a change in the particle size distribution of the clay in terms of increasing the number of larger fractions;

- in the areas adjacent to the electrodes, due to draining of the accumulated liquid, the moisture decreases, and an increase in the percentage of coarse fraction leads to a decrease in the density of the soil in the wet and in the dry state;

- from the beginning of the oil products coagulation process at $t>3$ days, the process of an increase in electrical resistivity is relatively monotonous both near the electrodes and in the center of the transition area when treating the soils mixed with viscous heavy liquids (oil, fuel oil), while for light fractions (gasoline, diesel) this process is characterized by a decrease in electrical resistivity in the near-cathode area;

- The introduction of solvent in the soil promotes the formation of soil liquefaction zone around the electrode, with the direction of electro osmotic filtering corresponding to the predominance of positively charged ions in the solvent nHexane.

Thus, the oil in the pores acts as a bonding agent, but its effect is of a local nature at the level of the soil grains, and it is significantly different from the soil mass consolidation mechanism for two-solution [26] and one-solution [27] electrochemical consolidation.

It follows from the experimental results on the threedimensional model (see Figure 2) that the electro osmotic processes in the near-electrode regions in the processing of clean and oil contaminated soils are interconnected and have significant differences due to differences in conductive 
properties of the aqueous solution (low electrical resistivity) and engine oil (dielectric):

- In a clean soil, the moisture progressively moves from the cathode to the anode accompanied by a decrease in the electrical resistivity in the moisture accumulation zone and an increase in electrical resistivity in the electrical drying zone, while the anode drying zone exceeds the moisture saturation zone by its extension, the formation of these zones is fast enough in $3.0-3.5 \mathrm{~A} \cdot \mathrm{h}$ from the start of electric treatment;

- In the polluted soil, a wavy character of changes in the electrical resistivity was observed due to the fact that the oil viscosity is considerably higher than that of the aqueous solution, wherein the positive increments of resistivity

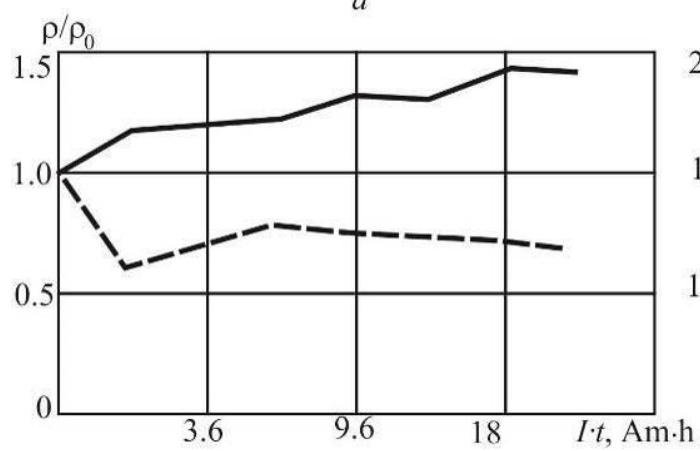

corresponding to the predominance of oil products in the pores, and the negative ones corresponding to the predominance of the aqueous solution during become more contrasting in the course of treatment and move to the area of the anode; in the cathode area, with the outflow of moisture electrical resistivity changes insignificantly indicating the predominant influence of mineral oil grains insulation by the oil film.

The temporary nature of the processes described above in the electrode regions on the main axis of the treatment is characterized by the graphs of dependences of the relative electrical resistivity $\rho / \rho_{0}$ in the characteristic points in the soil mass on the electric current rate $I \cdot t$ given in Figure 7.

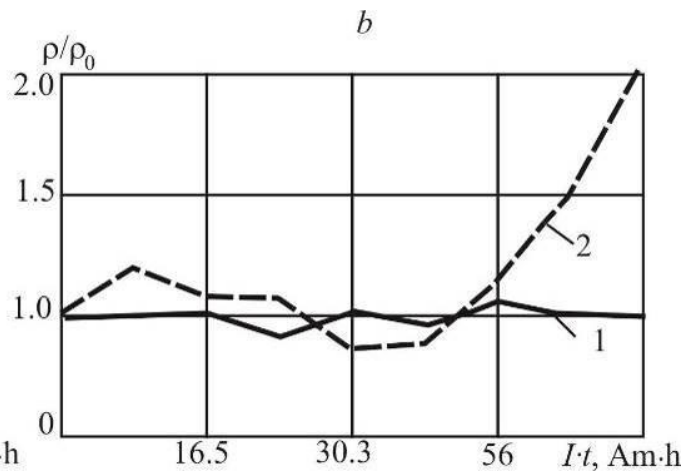

Fig. 7. Change in electrical resistivity of a clean soil $(a)$ and soil contaminated with waste oil SHELL HELIX $(b)$ in the electrochemical treatment of soil: 1 - on sensor \# 1 near the negative electrode; 2 - on sensor \# 8 near the positive electrode.

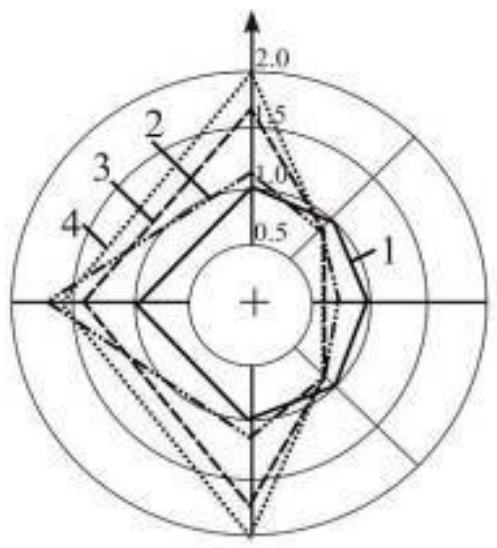

$a$
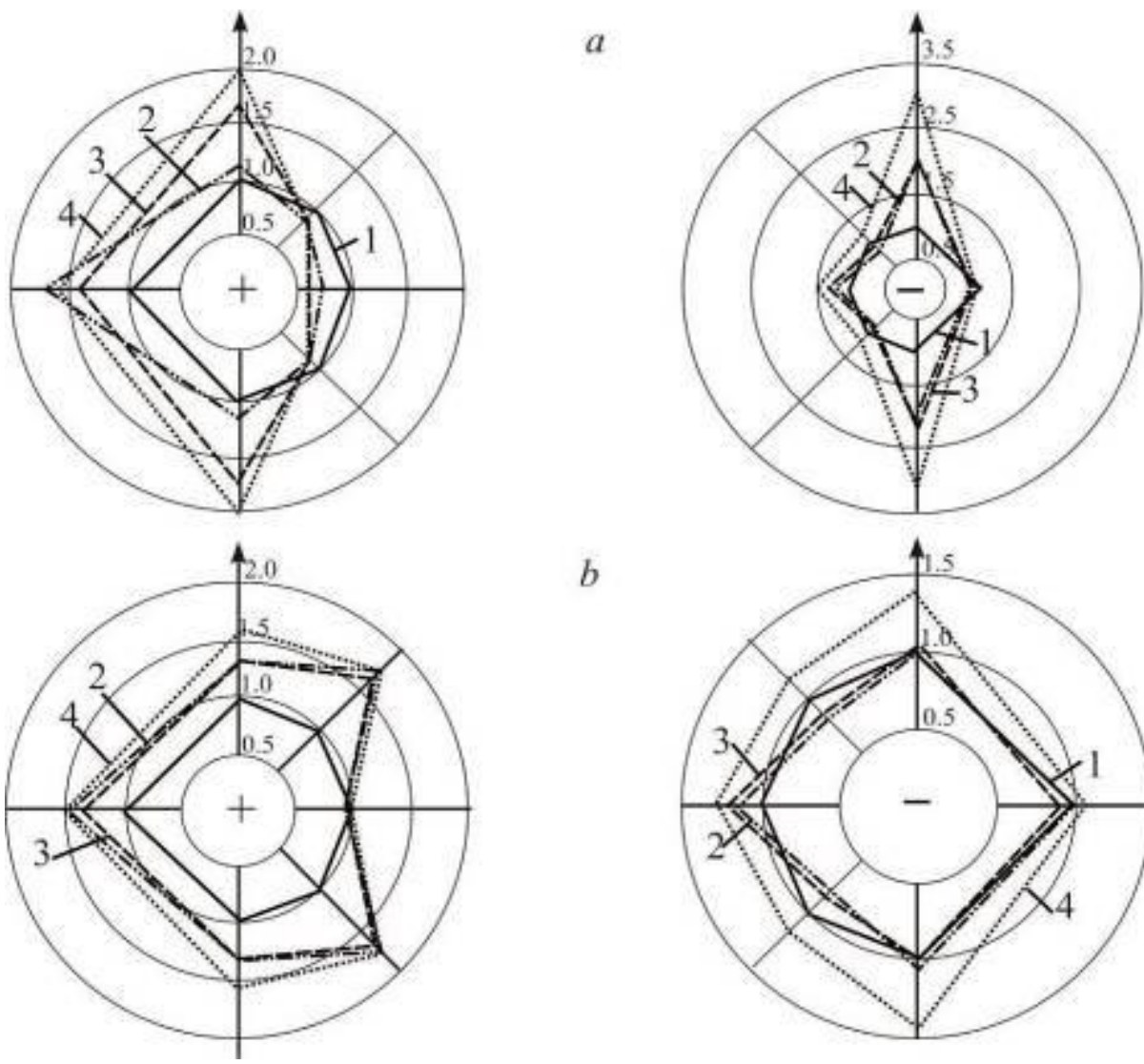

$b$

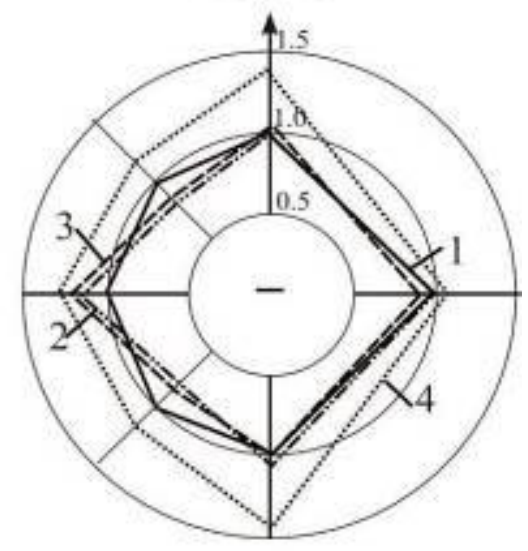

Fig. 8. Circular diagrams of electrical resistivity changes for clean soil during electrochemical treatment at $\mathrm{r}=90 \mathrm{~mm}(a)$ and $\mathrm{r}$ $=150 \mathrm{~mm}(b)$ at different flow rates of electric current $I \cdot t: 1-$ start of treatment; $2-6 \mathrm{Am} \cdot \mathrm{h} ; 3-13.5 \mathrm{Am} \cdot \mathrm{h} ; 4-22.5 \mathrm{Am} \cdot \mathrm{h}$ 

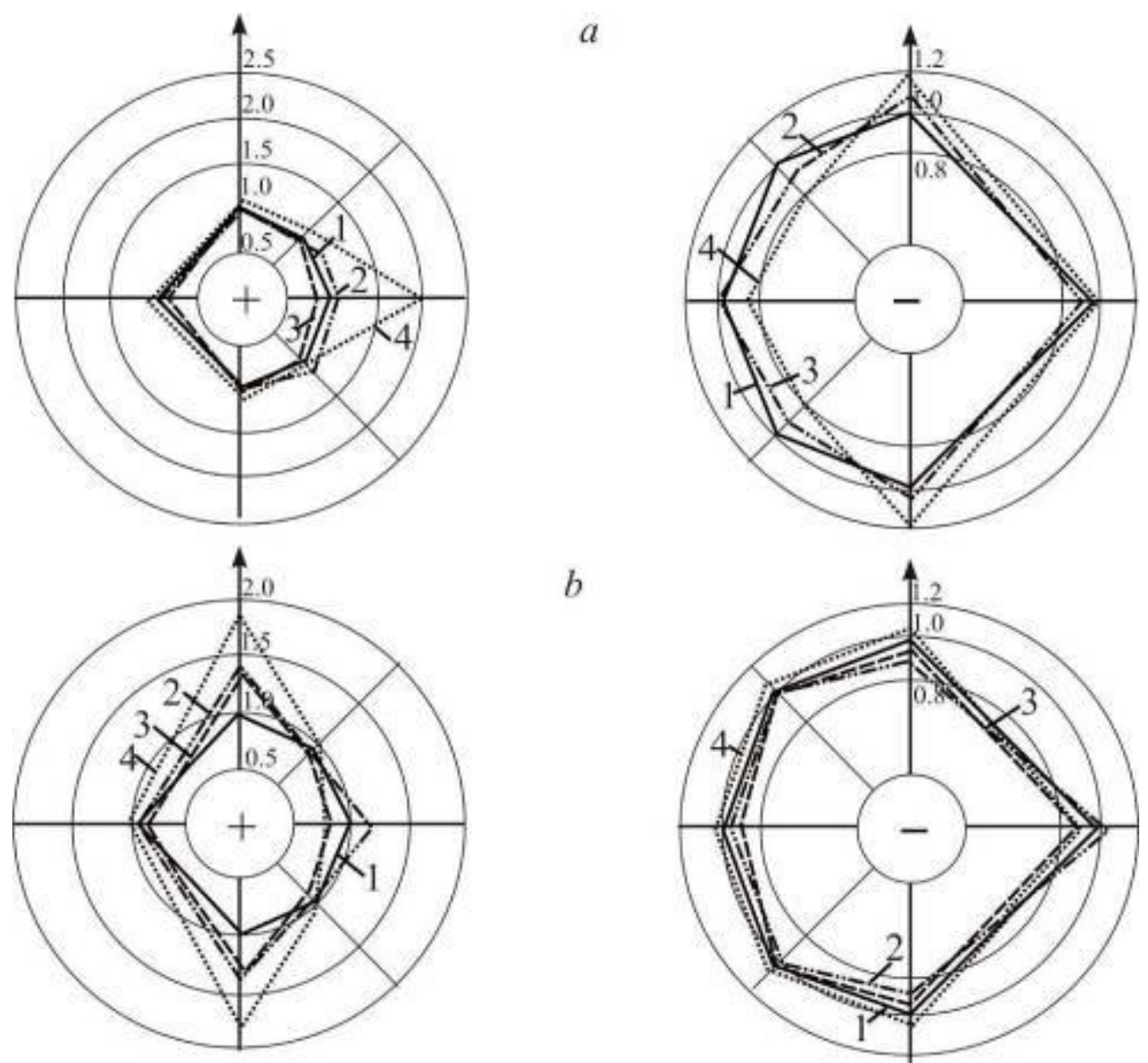

$b$

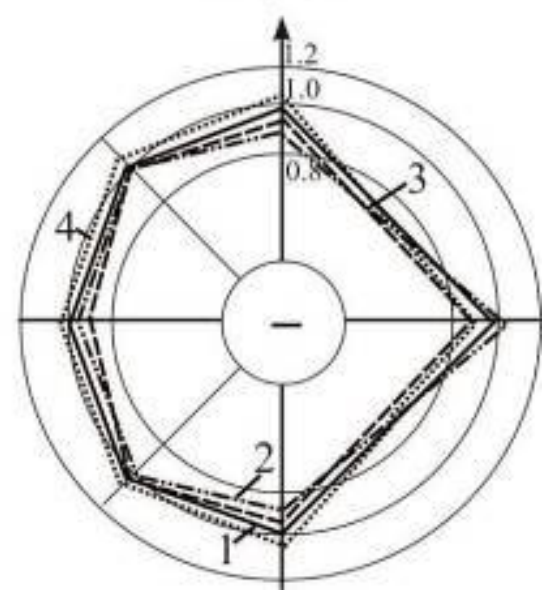

Fig. 9. Circular diagrams of the change in electrical resistivity of the soil contaminated with waste oil during electrochemical treatment at $r=90 \mathrm{~mm}(a)$ and $r=150 \mathrm{~mm}(b)$ at different flow rates of electric current $I \cdot t: 1-$ start of treatment; $2-21.3 \mathrm{Am} \cdot \mathrm{h}$; 3-30.3 Am.h; $4-65.1 \mathrm{Am} \cdot \mathrm{h}$

The hydrodynamic processes in the near-electrode areas are characterized by circular diagrams of electrical resistivity given in Figures 8 and 9.

The following features of formation of near electrode volume areas are identified:

- Around the anode in the pure soil the asymmetry of electrical resistivity is observed, the moisture accumulation zone with $\rho / \rho_{0}=0.6-0.7$ corresponds to the circular sector in the range $\Delta \varphi=90-120^{\circ}$; the outflow of fluid is fixed from the lateral and return directions; in the vicinity of the electrodecathode the thermal soil drainage area is formed $(r=90 \mathrm{~mm})$, as the distance from the electrode axis increases, the anisotropy of electrical resistivity is significantly mitigated;

- in the polluted soil in the near-cathode zone there is no pronounced layer of thermal drying recorded; in other aspects, the structure of this zone doesn't differ from the pure soil; in the near-anode volume, the oil accumulation sector reaches $\Delta \varphi$ $=180^{\circ}$.

\section{CONCLUSIONS}

The analysis of the experimental data provided the following most important scientific positions.

1. It is advisable to carry out the location of zones contaminated by petroleum products by the method of electrical resistivity: in a pointed way by buried micro sensors; probing from the earth's surface. The error of soil contamination coefficient prediction (ratio by volume) before transition of the soil into the plastic state does not exceed $23 \%$.

2. In electric treatment, the contaminated soil mass is exposed to electro osmotic and electro-thermal impacts. As a result of the electro thermal impact on oil products in the pores of the soil, these products transit in a solid bound state which results in the increase of the soil resistivity throughout the treatment area, and to a decrease in the soil moisture and density. As the result of electro osmotic impact of DC current, solid particles are formed and stick together leading to the 
change in particle size distribution of clay soil towards an increase in the content of larger fractions.

\section{ACKNOWLEDGMENT}

The authors are grateful to OOO "NOOCENTER" (O. V. Gerasimov, Director General, Ph.D. in Technical Sciences) for the material support with creating of the laboratory installations.

\section{REFERENCES}

[1] Horoshilova, L. S. Geojekologicheskoe sostojanie ugledobyvajushhih regionov Kuzbassa [The ecological state of the coal mining regions of Kuzbass]. - Kemerovo: Kuzbassvuzizdat, 2007. - 135 p.

[2] Korolev, V. A. Ochistka gruntov ot zagrjaznenij [Clean soil from pollution]. - Moskva: MAIK "Nauka / Interperiodika", 2001. - 365 p.

[3] Suhonosova, A. N. Ochistka pochv ot neftjanogo zagrjaznenija i ocenka ee jef-fektivnosti [Cleaning soil from oil pollution and evaluation of its effectiveness] / A. N. Suhonosova, V. A. Burlaka, D. E. Bykov [i dr.] // Jekologija i pro-myshlennost' Rossii [Ecology and Industry of Russia]. 2009. - \# 10. - P. 18-20.

[4] Archegova I. B., Khabibullina F. M., Shubakov A. A. Optimization of the purification of soil and water objects from oil using biosorbents. Contemporary Problems of Ecology. 2012. No.6. pp.548-553

[5] Ahmetzjanova, L. G. Primenenie metodov statisticheskogo analiza dlja opre-delenija bezopasnogo soderzhanija nefteproduktov v seroj pochve [Application of the methods of statistical analysis to determine safe concentrations of petroleum products in the gray soil] / L. G. Ahmetzjanova, A. A. Savel'ev, S. Ju. Selivanovskaja // Sibirskij jekologicheskij zhurnal [Siberian Journal of Ecology]. - 2014. - \# 6. P. 777-783.

[6] Trusei I. V., Ozerskii A. Yu., Ladygina V. P. Distribution of microorganisms in the oil-polluted ground of vadose and saturation zones. Contemporary Problems of Ecology. 2009. No.1. pp. 22-26

[7] Kolesnikov S. I., Zharkova M. G., Kazeev K. Sh. Ecotoxicity assessment of heavy metals and crude oil based on biological characteristics of chernozem. Russian Journal of Ecology. 2014. No.3. pp. 157-166.

[8] Efremova V. A., Dabakh E. V., Kondakova L. V. A chemical and biological assessment of the state of urban soils. Contemporary Problems of Ecology. 2013. No.5. pp. 561-568.

[9] Korzhov Yu. V., Lapshina E. D., Khoroshev D. I. CLEANSOIL as a perspective method of remediation of oil-contaminated soils under existing infrastructure. Contemporary Problems of Ecology. 2010. No.3. pp. 292-298

[10] Vorobeichik E. L., Kozlov M. V. Impact of point polluters on terrestrial ecosystems: Methodology of research, experimental design, and typical errors. Russian Journal of Ecology. 2012. No.2. pp. 89-96

[11] Seredina V. P., Sadykov M. E. The soils of West Siberia middle taiga oil deposits and a predictive estimate of contamination hazard with organic pollutants. Contemporary Problems of Ecology. 2011. No.5. pp. 457459.

[12] Lomize, G. M. Jelektroosmoticheskoe vodoponizhenie [Electro osmotic dewatering] / G. M. Lomize, A. V. Netushil. - Moskva ; Leningrad : Gosjenergoizdat, 1958. - $178 \mathrm{p}$.

[13] Stradanchenko, S. G. Issledovanie parametrov himicheskogo i jelektrohimicheskogo zakreplenija gruntov [Investigation of the parameters of the chemical and electrochemical grouting] / S. G.
Stradanchenko, P. N. Dolzhikov, A. A. Shubin. - Novocherkassk : JuRGTU (NPI), 2009. - 198 p.

[14] Prostov, S. M. Jelektrohimicheskoe zakreplenie gruntov [Electrochemical grouting] / S. M. Prostov, A. V. Pokatilov, D. I Rudkovskij ; RAEN. - Tomsk : Izd-vo Tomskogo universiteta, 2011. 294 p.

[15] Korolev, V. A., Romanyukha O .V., Abyzova A. M. Electrokinetic remediation of oil-contaminated soils. Journal of Environmental Scince and Health. Part A: Toxic. Hazardous Substances and Environmental Engineering. 2008. T. 43. No.8. pp. 876-880

[16] Korolev, V. A. Jelektrohimicheskaja ochistka gruntov ot jekotoksikantov: itogi i perspektivy [Electrochemical cleaning of soils from toxicants: results and prospects] // Vestnik Moskovskogo universiteta. Serija 4: Geologija [Bulletin of Moscow University. Series 4: Geology]. 2008. - \# 1. - P. 13-20.

[17] Zlochevskaja, R. I. Jelektropoverhnostnye javlenija v glinistyh porodah [Electrosurface phenomena in clay rocks]. - Moskva: Iz-vo MGU, 1988. $-177 \mathrm{p}$.

[18] Korolev, V. A. Teorija jelektropoverhnostnyh javlenij v gruntah i ih primenenie [Theory electrosurface phenomena in soils and their application]. - Moskva : OOO "Sam poligrafist", 2015. - $468 \mathrm{p}$.

[19] Dahnov, V. N. Jelektricheskie i magnitnye metody issledovanija skvazhin [Electrical and magnetic methods for wells]. - Moskva : Nedra, 1981. -344 p.

[20] Kobranova, V. N. Fizicheskie svojstva gornyh porod [Physical properties of rocks]. - Moskva : Gos. nauch.-tehn. izd-vo neftjanoj i gorno-toplivnoj lit., 1962. $-490 \mathrm{p}$.

[21] Prostov S. M., Khyamyalyainen V. A., Bakhaeva S. P. Interrelation among electrophysical properties of clay rocks, their porosity and moisture saturation // Journal of Mining Science. 2006. No.4. pp.349359

[22] Shtumpf, G. G. Fiziko-tehnicheskie svojstva gornyh porod i uglej Kuzneckogo bassejna [Physical and technical properties of rocks and coals of Kuznetsk basin] / G. G. Shtumpf, Ju. A. Ryzhkov, V. A. Shalamanov[i dr.]. - Moskva : Nedra, 1994. - 447 p.

[23] Rzhevskij, V. V. Osnovy fiziki gornyh porod: Uchebnik dlja vuzov [Fundamentals of rock physics]. - 4-e izd., pererab. i dop. / V. V. Rzhevskij, G. Ja. Novik. - Moskva : Nedra, 1984. - 359 p.

[24] Prostov, S. M. Metod ocenki zagrjaznenija nefteproduktami po jelektricheskim svojstvam gruntov [Method of evaluating oil contamination on the electrical properties of soils] / S. M. Prostov, M. V. Gucal, E. A. Shabanov // Vestnik Kuzbass. gosud. tehn. univ.. - 2015. \# 6. - P. 38-44.

[25] Sergey M. Prostov, Maxim V. Gucal, Evgeniy A. Shabanov. Physical basis of controlled electrochemical cleaning soils from petroleum. Proceedings of the Taishan Academic Forum - Project on Mine Disaster Prevention and Control / Atlantis Press. 2014. pp. 433-441

[26] Pokatilov, A. V. Kontrol' izmenenija fiziko-mehanicheskih svojstv massiva glinistyh gruntov pri jelektrohimicheskom zakreplenii [Control changes in physical and mechanical properties of the solid clay soils during electrochemical induration] / A. V. Pokatilov, S. M. Prostov // Vestnik Kuzbass. gosud. tehn. univ.-2006. - \# 4. - P. 10-14.

[27] Rudkovskij, D. I. Issledovanie faktorov, vlijajushhih na processy geleobrazovanija rastvorov dlja odnostadijnogo JeHZ [Investigation of factors influencing the process of gelling solutions for one-step electro chemical grouting] / D. I. Rudkovskij, S. M. Prostov, A. V. Pokatilov // Vestnik Kuzbass. gosud. tehn. univ. - 2008. - \#5. - P.18-22. 